\title{
Determining Heavy Metal Contents of Hollyhock (Alcea rosea L.) in Roadside Soils of a Turkish Lake Basin
}

\author{
Ilhan Kaya ${ }^{1 *}$, Füsun Gülser ${ }^{2}$ \\ ${ }^{1}$ Yuzuncu Yil University Agriculture Faculty, Department of Plant Protection, Van, Turkey \\ ${ }^{2}$ Yuzuncu Yil University Agriculture Faculty, Department of Soil Science, Van, Turkey
}

Received: 3 September 2017

Accepted: 26 October 2017

\begin{abstract}
This study was carried out to determine the heavy metal contents of hollyhock (Alcea rosea L.) in roadside soils of Van Lake Basin. The leaf samples of the hollyhock were taken from the roadside areas affected by heavy metal pollution due to intensive motorized traffic and from areas $30 \mathrm{~m}$ from the roadside by taking into account prevailing wind direction in 10 different locations. There were only significant differences for $\mathrm{Mn}, \mathrm{Cu}$, and $\mathrm{Zn}$ contents of leaves according to the sampling locations. The mean Fe (383.3 mg kg-1), Mn (50.2 $\left.\mathrm{mg} \mathrm{kg}^{-1}\right), \mathrm{Cu}\left(19.2 \mathrm{mg} \mathrm{kg}^{-1}\right), \mathrm{Zn}\left(23.9 \mathrm{mg} \mathrm{kg}^{-1}\right), \mathrm{Cd}\left(17.9 \mathrm{mg} \mathrm{kg}^{-1}\right)$, $\mathrm{Cr}\left(5.1 \mathrm{mg} \mathrm{kg}^{-1}\right)$, Ni $\left(3.2 \mathrm{mg} \mathrm{kg}^{-1}\right)$, and $\mathrm{Pb}\left(3.2 \mathrm{mg} \mathrm{kg}^{-1}\right)$ contents of leaves sampled from roadside areas were significantly higher than mean heavy metal contents of leaves sampled from the areas $30 \mathrm{~m}$ from the roadside. The increasing ratios in mean heavy metal contents of leaves were ordered as $\mathrm{Cd}(309.3 \%)$ $>\mathrm{Cr}(248.9 \%)>\mathrm{Ni}(130.6 \%)>\mathrm{Fe}(75.9 \%)>\mathrm{Pb}(64.3 \%)>\mathrm{Mn}(40.6 \%)>\mathrm{Cu}(26.1 \%)>\mathrm{Zn}(22.7 \%)$. High heavy metal uptake by the plants grown near the roadside occurred due to pollution by intensive motorized traffic.
\end{abstract}

Keywords: hollyhock, wild plant, heavy metal, traffic, road

\section{Introduction}

The toxic chemical substances released into the environment have adversely affected the natural environment, human health, and agricultural production efficiency [1]. The contamination of agricultural soils with several heavy metals including cadmium, lead, copper, and chromium has been widely reported [2].

*e-mail: ilhank@yyu.edu.tr
Much research has been conducted regarding heavy metal contents in soils of Turkey and European Union Countries. The heavy metal contents of soils in Turkey's Bartin Region have been reported for $\mathrm{Pb}, \mathrm{Zn}, \mathrm{Ni}, \mathrm{Cu}$, $\mathrm{Cd}, \mathrm{Mn}, \mathrm{Cr}$, and $\mathrm{Fe}$ in the range of $100-400 \mathrm{mg} \mathrm{kg}^{-1}$, 20-300 mg kg-1, 1-100 mg kg-1, 50-100 mg kg-1, 1-3 mg kg, $1-60 \mathrm{mg} \mathrm{kg}$, $1-150 \mathrm{mg} \mathrm{kg}$, and $1-1,000 \mathrm{mg} \mathrm{kg}^{-1}$, respectively [3]. The highest mean values of $\mathrm{Al}, \mathrm{Cd}, \mathrm{Cr}$, and $\mathrm{Pb}$ in cultivated soils of Van Lake Basin in Turkey were determined as $103.57 \mathrm{mg} \mathrm{kg}^{-1}, 0.514 \mathrm{mg} \mathrm{kg}^{-1}, 2.79 \mathrm{mg} \mathrm{kg}{ }^{-1}$, and $2.48 \mathrm{mg} \mathrm{kg}^{-1}$, respectively [4]. The limit values for $\mathrm{Cu}$, $\mathrm{Zn}, \mathrm{Cd}, \mathrm{Cr}, \mathrm{Ni}, \mathrm{Pb}, \mathrm{Co}$, and $\mathrm{Hg}$ in European Union soils 
were reported as $100 \mathrm{mg} \mathrm{kg}{ }^{-1}, 200 \mathrm{mg} \mathrm{kg}{ }^{-1}, 1 \mathrm{mg} \mathrm{kg}^{-1}$, $100 \mathrm{mg} \mathrm{kg}^{-1}, 50 \mathrm{mg} \mathrm{kg}{ }^{-1}, 60 \mathrm{mg} \mathrm{kg}{ }^{-1}, 20 \mathrm{mg} \mathrm{kg}$, and $0.5 \mathrm{mg} \mathrm{kg}^{-1}$, respectively [5]. In another study, the mean values of $\mathrm{Pb}, \mathrm{Cu}$, As, and $\mathrm{Hg}$ in Belgrade-PreSevo soils were determined as $40.94 \mathrm{mg} \mathrm{kg}^{-1}, 25.25 \mathrm{mg} \mathrm{kg}^{-1}$, $7.69 \mathrm{mg} \mathrm{kg}^{-1}$, and $0.13 \mathrm{mg} \mathrm{kg}^{-1}$, respectively [6].

Heavy metals such as $\mathrm{Cd}, \mathrm{Cu}, \mathrm{Co}, \mathrm{Ni}$, and $\mathrm{Pb}$ are reported as important elements not only because of the long-term accumulation in humans but because of the high potential for root uptake and accumulation in aboveground plant parts [7]. Heavy metals are among the most harmful environmental pollutants, and many researchers have reported their effects on plants and soil in areas close to main roads and motorways [810]. Traffic is a common source of soil and plant contamination with heavy metals [11]. Although some elements are necessary for the growth and development of crops, heavy metals at high concentrations affect plants toxically [12].

In modern cities there is heavy traffic and the total number of vehicles operating in urban areas has rapidly increased in recent history. Heavy traffic can produce a lot of road dust in urban areas. Heavy metals produced by vehicular exhaust and road, tire, and brake abrasion can be deposited in road dust [13].

Heavy metals are also found in fuels, in the wall of fuel tanks, in engines and other vehicle components, tires, as well as road surface materials [14-15]. Plants have been reported as intermediates in which heavy metals in soil, air, and water are transferred to the human body through consumption [13].

Metals such as $\mathrm{Cr}, \mathrm{Mn}, \mathrm{Zn}$, and $\mathrm{Cu}$ are generally found in low concentrations in green plants, which have no effect on the health of the organisms in the food chain [16]. However, in industrial, urban, and roadside areas their concentrations in plants may increase up to toxic levels for the health of living organisms [17].

Heavy metals and elements are accumulated in the roots and shoots by some plant species because of their high tolerance capabilities to heavy metal toxicity.
Therefore, it is necessary to investigate concentrations of heavy metals and accumulation of heavy metals in edible plants.

Medicinal plants are the primary source of health care for the majority of the world population. Therefore, investigating the content of heavy metals in medicinal plants contaminated by toxic metals has high importance [18].

Alcea rosea (L.) belong to the Malvaceae family and is a wild medicinal plant. The plant is native to China, Southern Europe, the Middle and Near East, and Mediterranean and Central Regions. A. rosea is a popular garden plant. On the other hand, it is widely used traditionally for the treatment of the irritation of oral, pharyngeal mucosa, and associated dry cough, mild gastritis, skin burns, and for insect bites. It is also used to treat catarrh of the mouth and throat, gastrointestinal and urinary tract complains, ulcers, abscesses, inflammation, burns, diarrhea, and constipation [19].

The objective of this study was to determine the potential of heavy metal (Fe, Mn, $\mathrm{Cu}, \mathrm{Zn}, \mathrm{Cd}, \mathrm{Cr}, \mathrm{Ni}$, and $\mathrm{Pb}$ ) contamination in leaves of Alcea rosea (L.) growing on roadside soils.

\section{Material and Methods}

This study was conducted in urban roadside areas and areas far from roadside areas in Van Lake Basin. The plant samples were taken from 10 different locations (Fig. 1) by taking into account prevailing wind direction. GPS readings belonging to sampling locations and traffic intensity are given in Table 1.

Hollyhock leaf samples were taken from the roadside areas affected by heavy metal pollution due to intensive motorized traffic, and areas $30 \mathrm{~m}$ from the roadside in 10 locations. A total set of 40 plant samples was taken from 2 sampling points according to the roadside $(0 \mathrm{~m}$ and $30 \mathrm{~m}$ ) in each location. Plant samples were washed, dried, and crushed for heavy metal element analyses.

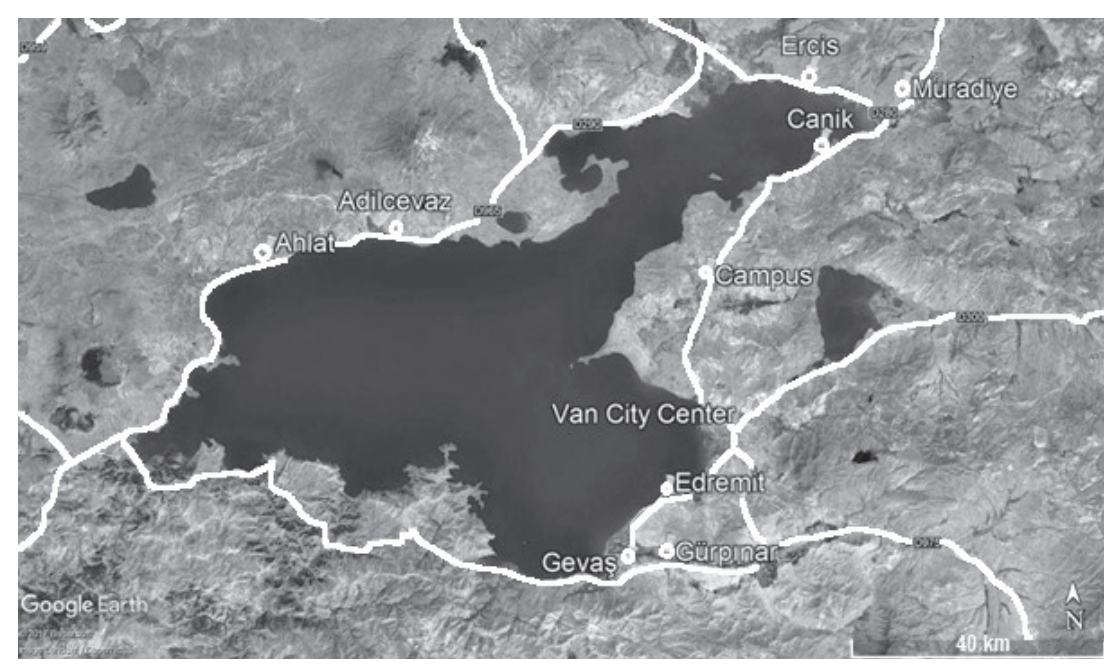

Fig. 1. Plant samples collected from different locations of Van Lake Basin. 
Table 1. GPS readings of sampling locations.

\begin{tabular}{|c|c|c|c|}
\hline Locations & Altitude & Coordinates & $\begin{array}{c}\text { Traffic intensity* } \\
\text { vehicle/day }\end{array}$ \\
\hline Campus & $1,740 \mathrm{~m}$ & $\begin{array}{l}\text { N } 38^{\circ} 43^{\prime}, 17.4 " \\
\text { E } 43^{\circ} 20^{\prime} 18.7 "\end{array}$ & 9,736 \\
\hline Canik & $1,705 \mathrm{~m}$ & $\begin{array}{l}\text { N } 38^{\circ} 53^{\prime} 23.6^{\prime \prime} \\
\text { E } 43^{\circ} 32^{\prime} 36.7^{\prime \prime}\end{array}$ & 3,572 \\
\hline Muradiye & $1,669 \mathrm{~m}$ & $\begin{array}{l}\text { N } 38^{\circ} 57^{\prime} 44.1^{\prime \prime} \\
\text { E } 43^{\circ} 41^{\prime} 49.6^{\prime \prime}\end{array}$ & 2,915 \\
\hline Erciş & $1,689 \mathrm{~m}$ & $\begin{array}{l}\text { N } 38^{\circ} 58^{\prime} \\
\text { E } 43^{\circ} 36^{\prime} 07.5^{\prime \prime}\end{array}$ & 6,465 \\
\hline Adilcevaz & $1,654 \mathrm{~m}$ & $\begin{array}{l}\text { N } 38^{\circ} 47^{\prime}, 31.5^{\prime \prime} \\
\text { E } 42^{\circ} 46^{\prime} \\
12.3^{\prime \prime}\end{array}$ & 2,588 \\
\hline Ahlat & $1,666 \mathrm{~m}$ & $\begin{array}{l}\mathrm{N} 38^{\circ} 45^{\prime} 37.7^{\prime \prime} \\
\mathrm{E} 42^{\circ} 32^{\prime} 42.4^{\prime \prime}\end{array}$ & 6,289 \\
\hline Edremit & $1,659 \mathrm{~m}$ & $\begin{array}{l}\text { N } 38^{\circ} 25^{\prime}, 34.4^{\prime \prime} \\
\text { E } 43^{\circ} 15^{\prime} 41.3^{\prime \prime}\end{array}$ & 16,793 \\
\hline Gevaş & $1,685 \mathrm{~m}$ & $\begin{array}{l}\mathrm{N} 38^{\circ} 18^{\prime} \\
\mathrm{E} 43^{\circ} 10^{\prime} \\
\end{array}$ & 4,747 \\
\hline Gürpınar & $1,709 \mathrm{~m}$ & $\begin{array}{l}\text { N } 38^{\circ} 19^{\prime} 51.3^{\prime \prime} \\
\text { E } 43^{\circ} 13^{\prime} \\
57.4^{\prime \prime}\end{array}$ & 3,301 \\
\hline Van City-Center & $1,783 \mathrm{~m}$ & $\begin{array}{l}\text { N } 38^{\circ} 30^{\prime}, 15.2^{\prime \prime} \\
\text { E } 43^{\circ} 25^{\prime} \\
15.3^{\prime \prime}\end{array}$ & 32,312 \\
\hline
\end{tabular}

After plant leaf samples were digested with a mixture of nitric and percloric acid (3:1 ratio), Fe, Mn, $\mathrm{Cu}, \mathrm{Zn}, \mathrm{Cd}, \mathrm{Cr}, \mathrm{Ni}$, and $\mathrm{Pb}$ contents in leaves were analyzed by atomic adsorption spectrophotometer (Thermo ICE 3000 series) [20].

Variance analyses of the experimental data were done using an SPSS statistic program and differences between means (at $\mathrm{P}<0.05$ and $\mathrm{P}<0.01$ ) were tested by multiple comparisons using the least significant difference (LSD) test.

\section{Results and Discussion}

According to variance analyses results in Table 2, there were significant differences between the locations and the sampling positions $(0 \mathrm{~m}$ and $30 \mathrm{~m}$ away from the roadside) for heavy metals contents of leaves. Mean heavy metal contents of leaves in the sampling locations according to sampling positions are given in Table 3.

We found that mean $\mathrm{Fe}, \mathrm{Cu}, \mathrm{Cr}, \mathrm{Ni}$, and $\mathrm{Pb}$ contents of leaves significantly $(\mathrm{P}<0.05)$ decreased in plant leaves sampled from the roadside $(0 \mathrm{~m})$ to $30 \mathrm{~m}$ away from the roadside (Table 2). While the highest mean $\mathrm{Fe}, \mathrm{Mn}, \mathrm{Cu}, \mathrm{Zn}, \mathrm{Cd}, \mathrm{Cr}, \mathrm{Ni}$, and $\mathrm{Pb}$ contents were determined as $810.20 \mathrm{mg} \mathrm{kg} \mathrm{kg}^{-1}, 63.01 \mathrm{mg} \mathrm{kg}^{-1}$, $34.02 \mathrm{mg} \mathrm{kg}$, $29.12 \mathrm{mg} \mathrm{kg}{ }^{-1}, 25.08 \mathrm{mg} \mathrm{kg} \mathrm{kg}^{-1}$, $14.47 \mathrm{mg} \mathrm{kg}^{-1}$, $7.42 \mathrm{mg} \mathrm{kg}^{-1}$, and $7.00 \mathrm{mg} \mathrm{kg}^{-1}$ in leaves sampled from the roadside, respectively, the lowest mean heavy metal contents were $157.75 \mathrm{mg} \mathrm{kg}^{-1}, \quad 30.49 \mathrm{mg} \mathrm{kg}^{-1}, \quad 8.20 \mathrm{mg} \mathrm{kg} \mathrm{kg}^{-1}$, $13.89 \mathrm{mg} \mathrm{kg} \mathrm{kg}^{-1}, 0.01 \mathrm{mg} \mathrm{kg}^{-1}, 0.76 \mathrm{mg} \mathrm{kg}{ }^{-1}, 0.57 \mathrm{mg} \mathrm{kg}^{-1}$, and $0.70 \mathrm{mg} \mathrm{kg}^{-1}$ in leaves sampled $30 \mathrm{~m}$ away from the road, respectively.

It was reported that the means of $\mathrm{Fe}, \mathrm{Cu}, \mathrm{Zn}, \mathrm{Mn}$, and $\mathrm{Ni}$ of $A$. rosea seeds were determined as 24.38 , $0.016,0.179,0.526$, and $0.004 \mathrm{mg} \mathrm{kg}^{-1}$, respectively [21]. In another study, $\mathrm{Pb}, \mathrm{Cd}, \mathrm{Cu}, \mathrm{Zn}, \mathrm{Cr}$, and $\mathrm{Fe}$ contents in the stems of $A$. rosea were reported as 30.1, 0.67, 30.0, 93.6, 196.0, and $106.0 \mathrm{mg} \mathrm{kg}^{-1}$ of $A$. rosea [22].

There were significant differences for mean $\mathrm{Mn}$ $(\mathrm{P}<0.05), \mathrm{Cu}(\mathrm{P}<0.01)$, and $\mathrm{Zn}(\mathrm{P}<0.05)$ contents of leaves sampled from the different locations (Table 2). The highest mean $\mathrm{Mn}, \mathrm{Cu}$, and $\mathrm{Zn}$ contents in leaves were obtained as $52.61 \mathrm{mg} \mathrm{kg}^{-1}, 28.85 \mathrm{mg} \mathrm{kg}^{-1}$, and $26.10 \mathrm{mg} \mathrm{kg}^{-1}$ in Canik, Edremit, and Ahlat sampling locations, respectively (Table 4).

Table 2. F values of the variance analyses for the heavy metal contents of leaves.

\begin{tabular}{|c|c|c|c|c|c|c|c|c|c|}
\hline Variance source & $\mathrm{df}$ & $\mathrm{Fe}$ & $\mathrm{Mn}$ & $\mathrm{Cu}$ & $\mathrm{Zn}$ & $\mathrm{Cd}$ & $\mathrm{Cr}$ & $\mathrm{Ni}$ & $\mathrm{Pb}$ \\
\hline Sample positions & 1 & $7.80^{\mathrm{x}}$ & $44.78^{* *}$ & $9.38^{*}$ & $98.52^{* *}$ & $17.24^{* *}$ & $5.99^{*}$ & $2.51^{*}$ & $7.92^{*}$ \\
\hline Locations & 9 & $2.53^{\text {ns }}$ & $3.24^{*}$ & $11.46^{* *}$ & $22.13^{*}$ & $1.63^{\text {ns }}$ & $1.27^{\text {ns }}$ & $16.00^{\text {ns }}$ & $3.19^{\text {ns }}$ \\
\hline
\end{tabular}

ns: non-significant, * significant at 0.05 level, ${ }^{* *}$ significant at 0.01 level. 
Table 3. Mean heavy metal contents $\left(\mathrm{mg} \mathrm{kg}^{-1}\right)$ of leaves in different sampling locations according to sampling positions.

\begin{tabular}{|c|c|c|c|c|c|c|c|c|c|}
\hline Locations & Sampling positions & $\mathrm{Fe}$ & Mn & $\mathrm{Cu}$ & $\mathrm{Zn}$ & $\mathrm{Cd}$ & $\mathrm{Cr}$ & $\mathrm{Ni}$ & $\mathrm{Pb}$ \\
\hline Campus & $0 \mathrm{~m}$ & 437.30 & 51.84 & 16.86 & 24.30 & 34.12 & 14.47 & 2.86 & 3.24 \\
\hline Canik & $0 \mathrm{~m}$ & 198.00 & 63.01 & 10.76 & 18.48 & 25.08 & 2.31 & 1.24 & 1.53 \\
\hline Muradiye & $0 \mathrm{~m}$ & 264.95 & 41.66 & 12.74 & 24.98 & 22.19 & 1.29 & 2.00 & 3.16 \\
\hline Erciş & $0 \mathrm{~m}$ & 147.40 & 59.12 & 17.61 & 25.29 & 17.79 & 3.20 & 0.97 & 4.87 \\
\hline Adilcevaz & $0 \mathrm{~m}$ & 210.90 & 42.34 & 12.80 & 28.64 & 11.15 & 2.61 & 1.31 & 1.38 \\
\hline Ahlat & $0 \mathrm{~m}$ & 284.45 & 59.82 & 12.97 & 29.12 & 24.60 & 1.04 & 1.43 & 1.43 \\
\hline Edremit & $0 \mathrm{~m}$ & 810.20 & 52.97 & 34.02 & 24.94 & 1.80 & 13.52 & 7.04 & 2.89 \\
\hline Gevaş & $0 \mathrm{~m}$ & 218.45 & 36.62 & 19.00 & 16.76 & 15.78 & 1.57 & 3.62 & 7.00 \\
\hline Gürpınar & $0 \mathrm{~m}$ & 477.80 & 40.37 & 31.33 & 18.50 & 5.61 & 5.12 & 3.66 & 2.27 \\
\hline Van City-Center & $0 \mathrm{~m}$ & 783.75 & 54.08 & 23.79 & 28.52 & 17.22 & 5.45 & 7.42 & 4.46 \\
\hline Mean & $0 \mathrm{~m}$ & 383.32 & 50.18 & 19.19 & 23.95 & 17.93 & 5.06 & 3.16 & 3.22 \\
\hline Campus & $30 \mathrm{~m}$ & 230.10 & 38.21 & 16.83 & 20.63 & 6.50 & 2.02 & 1.49 & 3.240 \\
\hline Canik & $30 \mathrm{~m}$ & 157.85 & 42.21 & 9.15 & 13.89 & 16.15 & 0.89 & 1.62 & 1.33 \\
\hline Muradiye & $30 \mathrm{~m}$ & 160.40 & 35.75 & 10.54 & 20.38 & 2.80 & 0.76 & 0.57 & 1.33 \\
\hline Erciş & $30 \mathrm{~m}$ & 157.75 & 38.15 & 8.83 & 20.87 & 0.01 & 0.80 & 1.40 & 0.70 \\
\hline Adilcevaz & $30 \mathrm{~m}$ & 187.00 & 32.58 & 8.20 & 18.88 & 1.25 & 1.15 & 1.43 & 2.12 \\
\hline Ahlat & $30 \mathrm{~m}$ & 227.60 & 37.68 & 15.05 & 23.08 & 0.01 & 1.25 & 0.90 & 0.81 \\
\hline Edremit & $30 \mathrm{~m}$ & 303.80 & 32.02 & 23.68 & 19.00 & 0.01 & 1.87 & 1.55 & 2.00 \\
\hline Gevaş & $30 \mathrm{~m}$ & 173.45 & 32.86 & 13.71 & 17.28 & 10.95 & 2.19 & 1.42 & 4.06 \\
\hline Gürpınar & $30 \mathrm{~m}$ & 279.25 & 30.49 & 23.46 & 19.26 & 6.08 & 1.81 & 1.66 & 1.77 \\
\hline Van City-Center & $30 \mathrm{~m}$ & 301.90 & 36.93 & 22.79 & 21.87 & 0.01 & 1.72 & 1.62 & 2.24 \\
\hline Mean & $30 \mathrm{~m}$ & 217.91 & 35.69 & 15.22 & 19.51 & 4.38 & 1.45 & 1.37 & 1.96 \\
\hline
\end{tabular}

Iron contents of leaves sampled from the different locations were not statistically different from each other (Table 4). The high mean Fe contents were determined as $542.83 \mathrm{mg} \mathrm{kg}^{-1}$ and $557.00 \mathrm{mg} \mathrm{kg}^{-1}$ in Van City Center and Edremit sampling locations, respectively. These locations have more traffic density than the other locations (Table 1).

The normal $\mathrm{Ni}, \mathrm{Pb}$, and $\mathrm{Cu}$ levels in plant tissues are reported in the range of $0.1-5 \mathrm{mg} \mathrm{kg}^{-1}, 1-5 \mathrm{mg} \mathrm{kg}^{-1}$, and $3-15 \mathrm{mg} \mathrm{kg}^{-1}$, respectively [17-23]. In this study, Ni contents determined in leaves sampled from Edremit and Van-City Center were higher than the normal levels. The $\mathrm{Pb}$ contents in leaves were found in the range of normal level, except the plants sampled from the roadside of the Gevaş location, but it was not a critical level. The means of $\mathrm{Cu}$ in leaves were generally found to be higher than the normal level and some of them sampled from different positions and locations were at toxic levels (>20 $\mathrm{mg} \mathrm{kg}^{-1}$ ) (Tables 3 and 4) [24].

In plant tissues, $\mathrm{Zn}$ and $\mathrm{Cd}$ levels are reported as $50 \mathrm{mg} \mathrm{kg}^{-1}$ and $0.1 \mathrm{mg} \mathrm{kg}^{-1}$, respectively [25]. The means of $\mathrm{Zn}$ contents in leaves were in the normal range while the means of $\mathrm{Cd}$ contents in leaves were higher than the normal range level. According to the normal range values reported for $\mathrm{Mn}$ and $\mathrm{Cr}$ contents in plants [26], the mean Mn contents in leaves were in the normal range (15-100 $\left.\mathrm{mg} \mathrm{kg}^{-1}\right)$, the mean $\mathrm{Cr}$ contents in leaves were generally higher than the normal range (0.2-1.0 $\left.\mathrm{mg} \mathrm{kg}^{-1}\right)$.

Mean $\mathrm{Fe}$ contents of leaves sampled from the roadside position were generally higher than the range of normal levels (50.0-2.40 $\mathrm{mg} \mathrm{kg}^{-1}$ ) for shrubs and herbs reported in literature [28]. The normal $\mathrm{Ni}, \mathrm{Pb}$, and $\mathrm{Cu}$ levels in plant tissues are reported in the range of $0.1-5.0 \mathrm{mg} \mathrm{kg}{ }^{-1}, 1.0-5.0 \mathrm{mgkg}^{-1}$, and $3.0-15 \mathrm{mg} \mathrm{kg}^{-1}$, respectively [17-24]. In this study, Ni contents of leaves sampled from Edremit and Van-Center locations were found to be higher than normal levels. The contents of $\mathrm{Pb}$ in plants were found to be in a normal range, except for the $\mathrm{Pb}$ content of leaves sampled from a roadside position in the Gevaş location.

When compared to sampling positions $30 \mathrm{~m}$ away from the roadside, the increasing ratios in mean heavy metal contents of leaves sampled from the roadside $(0 \mathrm{~m})$ were ordered as $\mathrm{Cd}(309.3 \%)>\mathrm{Cr}(248.9 \%)>\mathrm{Ni}$ $(130.6 \%)>\mathrm{Fe}(75.9 \%)>\mathrm{Pb}(64.3 \%)>\mathrm{Mn}(40.6 \%)>\mathrm{Cu}$ 
Table 4. Mean heavy metal contents $\left(\mathrm{mg} \mathrm{kg}^{-1}\right)$ of leaves sampled from different locations.

\begin{tabular}{|c|c|c|c|c|c|c|c|c|}
\hline Locations & $\mathrm{Fe}$ & $\mathrm{Mn}$ & $\mathrm{Cu}$ & $\mathrm{Zn}$ & $\mathrm{Cd}$ & $\mathrm{Cr}$ & $\mathrm{Ni}$ & $\mathrm{Pb}$ \\
\hline Campus & 333.70 & $45.03 \mathrm{abc}$ & $16.85 \mathrm{bc}$ & $22.47 \mathrm{ab}$ & 22.31 & 8.25 & 2.18 & 3.24 \\
\hline Canik & 177.93 & $52.61 \mathrm{a}$ & $9.96 \mathrm{c}$ & $16.19 \mathrm{~d}$ & 20.62 & 1.60 & 1.43 & 1.43 \\
\hline Muradiye & 212.68 & $38.71 \mathrm{bc}$ & $11.64 \mathrm{c}$ & $22.68 \mathrm{ab}$ & 12.50 & 1.03 & 1.29 & 2.25 \\
\hline Erciş & 152.58 & $48.64 \mathrm{ab}$ & $13.22 \mathrm{bc}$ & $23.08 \mathrm{ab}$ & 8.90 & 2.00 & 1.19 & 2.76 \\
\hline Adilcevaz & 198.95 & $37.46 \mathrm{bc}$ & $10.50 \mathrm{c}$ & $23.76 \mathrm{ab}$ & 6.20 & 1.88 & 1.37 & 1.75 \\
\hline Ahlat & 256.03 & $48.75 \mathrm{ab}$ & $14.01 \mathrm{bc}$ & $26.10 \mathrm{a}$ & 13.31 & 1.15 & 1.17 & 1.12 \\
\hline Edremit & 557.00 & $42.50 \mathrm{abc}$ & $28.85 \mathrm{a}$ & $21.97 \mathrm{abc}$ & 0.91 & 7.70 & 4.30 & 2.45 \\
\hline Gevaş & 195.95 & $34.74 \mathrm{c}$ & $16.36 \mathrm{bc}$ & $17.02 \mathrm{~cd}$ & 13.37 & 1.88 & 2.52 & 5.53 \\
\hline Gürpinar & 378.53 & $35.43 \mathrm{c}$ & $27.40 \mathrm{a}$ & $18.88 \mathrm{bcd}$ & 5.85 & 3.47 & 2.66 & 2.02 \\
\hline Van City-Center & 542.83 & $45.51 \mathrm{abc}$ & $23.29 \mathrm{ab}$ & $25.20 \mathrm{a}$ & 8.62 & 3.59 & 4.52 & 3.35 \\
\hline Mean & $\mathbf{3 0 0 . 6 2}$ & $\mathbf{4 2 . 9 4}$ & $\mathbf{1 7 . 2 0}$ & $\mathbf{2 1 . 7 3}$ & $\mathbf{1 1 . 2 6}$ & $\mathbf{3 . 2 5}$ & $\mathbf{2 . 6 3}$ & $\mathbf{2 . 5 9}$ \\
\hline
\end{tabular}

$(26.1 \%)>\mathrm{Zn}(22.7 \%)$. The higher increasing ratios were determined in $\mathrm{Cd}, \mathrm{Cr}, \mathrm{Ni}$, and Fe contents. Alcea rosea (L.) has been reported to have a stronger $\mathrm{Cd}$ tolerance and accumulation capacity than other ornamental plants [27]. According to results of completed numerous studies, Impatiens balsamina, Calendula officinalis, and Alcea rosea had higher tolerance and accumulation ability to $\mathrm{Cd}$ and $\mathrm{Pb}$. [28]. Alternanthera bettzickiana having $\mathrm{Cd}$ accumulation property at high levels had $100 \mathrm{mg} \mathrm{kg}^{-1} \mathrm{Cd}$ content under $2.0 \mathrm{mM} \mathrm{Cd}$ treatment to growing media [29]. The treatment of $\mathrm{Cd}$ is higher than $20 \mathrm{mg} \mathrm{l}^{-1}$ and had no effect on germination rate and germination vigor of $A$. rosea seeds [30].

The means of $\mathrm{Cu}, \mathrm{Cr}$, and $\mathrm{Pb}$ contents in leaves were also at high levels in Campus, Edremit, and Gevaş sampling locations where these places have intense traffic. Vehicle emissions are considered one of the main sources of heavy metal contamination in urban areas. The sources of heavy metal pollution are mainly power stations, old coal-fired furnaces, and care combustion gases [31] in polluted air.

It was reported that some medicinal plants such as mint, lavender, marigold, hollyhock, garlic, and garden sorrel can accumulate high amounts of toxic heavy metals in their tissues [32]. Moreover, plants have good bio indicator properties [33].

Numerous studies have indicated that $\mathrm{Cd}, \mathrm{Fe}, \mathrm{Cu}$, $\mathrm{Cr}, \mathrm{Ni}$, and $\mathrm{Pb}$ contents of plants decrease related to increasing distance from roadsides [27-8]. Our results are in agreement with these findings. On the other hand, it has been reported that these heavy metal concentrations are usually at high levels in urban and industrial areas [18]. Generally, heavy metal contents of soils decrease with increasing distance from the pollutant emission sources [34].

It has been reported that traffic pollutants contain hazardous toxic metals for health such as $\mathrm{Pb}, \mathrm{Cd}$, and $\mathrm{Zn}$ [35]. In this study, higher $\mathrm{Fe}, \mathrm{Mn}, \mathrm{Cu}, \mathrm{Zn}, \mathrm{Cd}, \mathrm{Cr}$,
$\mathrm{Ni}$, and $\mathrm{Pb}$ contents in plant tissues were determined in roadside areas influenced by motorized traffic.

It is known that herbs growing in the natural habitat and used for medicinal purposes have an ability to accumulate heavy metals in their tissues [36-37]. In this study hollyhock accumulated heavy metals due to motorized traffic. Perennial plants like Althea rosea have significant heavy metal levels compared to those of monocarpic plants [38].

It has been reported that $\mathrm{Cd}$ accumulation in shoots and roots was up to 131.9 and $67.5 \mathrm{mg} \mathrm{kg}^{-1}$, respectively, when soil $\mathrm{Cd}$ was $30 \mathrm{mg} \mathrm{kg}^{-1}$, and 178.5 and $135.6 \mathrm{mg} \mathrm{kg}^{-1}$, respectively, when soil $\mathrm{Cd}$ was $100 \mathrm{mg} \mathrm{kg}^{-1}$ [39]. Thus Alcea rosea is regarded as a potential $\mathrm{Cd}$ hyperaccumulator. A. rosea accumulated $\mathrm{Cd}, \mathrm{Cr}, \mathrm{Ni}$, and $\mathrm{Fe}$ caused by intensive traffic.

Euroasian people used the various subspecies of this plant genus since very ancient times. Alcea rosea is the most investigated subspecies of Alceae. Antioxidant activity was reported for Alcea rosea [40-42]. Alcea subspecies having A. pallida [43] and A. rosea [39] were reported as heavy metal accumulators.

\section{Conclusions}

As a result, the highest $\mathrm{Fe}, \mathrm{Mn}, \mathrm{Cu}, \mathrm{Zn}, \mathrm{Cd}, \mathrm{Cr}, \mathrm{Ni}$, and $\mathrm{Pb}$ means were determined in the sampling position close to the roadside. The lowest mean Fe, $\mathrm{Mn}, \mathrm{Cu}, \mathrm{Zn}$, $\mathrm{Cd}, \mathrm{Cr}, \mathrm{Ni}$, and $\mathrm{Pb}$ contents in leaves were obtained in the sampling point $30 \mathrm{~m}$ from the roadside. The significant differences were found for mean $\mathrm{Mn}, \mathrm{Cu}$, and $\mathrm{Zn}$ contents of leaves sampled from the different locations. The highest mean $\mathrm{Mn}, \mathrm{Cu}$, and $\mathrm{Zn}$ contents in leaves were obtained in Canik, Edremit, and Ahlat sampling locations. The higher mean Fe contents in plant tissue were obtained in Van City Center and Edremit sampling locations. These locations have more traffic 
density than the other locations. In this study, generally heavy metal contents of leaves decreased with increasing distance from roads in all locations. The higher increasing ratios in heavy metal contents of leaves were $\mathrm{Cd}>\mathrm{Cr}>\mathrm{Ni}>\mathrm{Fe}$. It can be concluded that the results of this study may illuminate the heavy metal toxicity risk of herbal plants like Alcea rosea grown in roadside areas.

\section{References}

1. UGULU I. Determination of heavy metal accumulation in plant samples by spectrometric techniques in Turkey. Appl. Spectrosc. Rev., 50, 113, 2015.

2. ADREES M., ALI S., RIZWAN M., ZIA-UR-REHMAN M., IBRAHIM., ABBAS F., FARID M., QAYYUM M.F., IRSHAD M.K. Mechanisms of silicon-mediated alleviation of heavy metal toxicity in plants. Ecotoxicology Environmental Safety, 119, 186, 2015.

3. OZEL H.U., ÖZEL H.B. Investigation on heavy metal pollution in Uludag Fir Forests (Abies nordmanniana subsp. bornmülleriana MATTF) in the Bartın Region. Kastamonu Univ., Forest Faculty Journal, Special Issue 155, 2012.

4. KARACA S., GÜLSER F. Some heavy metal contents related with different physiographic Units and Land Use in Van Lake. Basin International Journal of Secondary Metabolite, 2 (2), 37, 2015.

5. TÓTH G., HERMANN T., DA SILVA M.R., MONTANARELLA L. Heavy metals in agricultural soils of the European Union with implications for food safety. Environment International, 88, 299, 2016.

6. PIVIC R., STANOJKOVIC-SEBIC A., JOSIC D., DINIC Z. Evaluation of the heavy metals content in soil and plant material at different distances from the motorway E75 in the section Belgrade-PreSevo (SERBIA). Bulgarian Journal of Agricultural Science, 20 (2), 330, 2014.

7. DATSENKO V.V., KHIMENKO N.L. Evaluation of heavy metal complex phytotoxicity. Eurasian Journal of Soil Science, 5 (3), 249, 2016.

8. GÜLSER F., ÇIĞ A., SÖNMEZ F. The determination of phytoremediation levels of ornamental plants used in landscape. J. Int. Environmental Application \& Science, 6 (5), 661, 2011.

9. JANKOWSKI K., CIEPIELA A.G., JANKOWSKA J., SZULC W., KOLCZAREK R., SOSNOWSKI J., WIŚNIEWSKA-KADŻAJAN B., MALINOWSKA E., RADZKA E., CZELUŚCIŃSKI W., DESKA J. Content of lead and cadmium in aboveground plant organs of grasses growing on the areas adjacent to a route of big traffic. Environmental Science and Pollution Research, 22 (2), 978, 2015.

10. MALINOWSKA E., JANKOWSKI K., SOSNOWSKI J., WIŚNIEWSKA-KADŻAJAN B. Pesticide residues in cereal crop grains in Poland in 2013. Environmental Monitoring and Assessment 187: 329. doi: 10.1007/s10661015-4566-7, 2015.

11. GWOREK B., DECKOWSKA A., PIERSCIENIAK M. Traffic pollutant indicator: Common dandelion (Teraxacum officinale), scots pine (Pinus silvestris), small-leavud lime (Tilia cordata). Polish Journal of Environmental Studies, 20 (1), 87, 2011.

12. SZYNKOWSKA M.I., PAWLACZYK A., LEŚNIEWSKA E., PARYJCZAK T. Toxic metal distribution in rural and urban soil samples affected by industry and traffic. Polish Journal of Environmental Studies, 18 (6), 1141, 2009.

13. DUONG T.T.T., LEE B.K. Determining contamination level of heavy metals in road dust from busy traffic areas with different characteristics. J Environ Manag., 92 (3), 554, 2011

14. ZEHETNER F., LAIR G.J., GRAF M, GERZABEK M.H. Rates of biogeochemical phosphorus and copper redistribution in young floodplain soils. Biogeosciences, $\mathbf{6}$, 2949, 2009.

15. DESKA J., BOMBİK A., MARCINIVIK-KUSKA A., RZYMUZA K. Trendsin lead and cadmium content in soils adjacent to Europiean Highway 30. Polish Journal of Environmental Studies, 20 (2), 317, 2011.

16. SAGLAM C. Heavy metal accumulation in the edible parts of some cultivated plants and media samples from a volcanic region in Southern Turkey. Ekoloji, 22, 86, 1, 2013.

17. ELEKES C.C., BUSUIOC G., IONITA G. The bioaccumulation of some heavy metals in the fruiting body of wild growing mushrooms. Notulae Botanicae Horti Agrobotanici Cluj-Napoca, 38, 147, 2010.

18. ONDER S., DURSUN S., GEZGIN S., DEMIRBAS A. Determination of heavy metal pollution in grass and soil of city centre green areas (Konya, Turkey). Polish Journal of Environmental Studies, 16 (1), 145, 2007.

19. PHARM TECH. http://www.pharmtech.com/Advancing Development and Manufacturing, 2016.

20. KACAR B., INAL A. Plant Analysis. Nobel Press, Istanbul, Turkey, ISBN 978-605-395-036-3, 2008.

21. SADIGHARA P., GHARIBI S., MOGHADAM JAFARI A., JAHED KHANIKI G., SALARI S. The antioxidant and flavonoids contents of Althaea officinalis L. flowers based on their color Avicenna. J. Phytomed., 2 (3), 113, 2012.

22. YIN-PING L., LI G., JIN L., XIAO-YIN Z. Spectroscopy. Spect. Anal., 2, 3147, 2009.

23. KLOKE A., SAUERBECK D.R., VETTER H. The contamination of pants and soils with heavy metals and the transport of metals in terrestrial food chains. in: J.O. Nriagu, Editor, Changing Metal Cycles and Human Health: Report of the Dahlem Workshop on Changing Metal Cyclesand Human Health, Germany, Springer, berlin, 113, 1984.

24. KASTORI R., PETROVIĆ N., ARSENIJEVIĆMAKSIMOVIĆ I., TEŠKI METALI I., BILJKE U., TEŠKI METALI U., ZIVOTNOJ SREDINI (R. Kastori, ed.). Naučni Institut za Ratarstvo i Povrtarstvo, Novi Sad, 196, 1997 [In Serbian].

25. MARKERT B. Plants as Biomonitors for Heavy Metal Pollution of the Terrestrial Environment. VCH, Weinheim, 1994.

26. ALLAWAY W.H. Agronomic control over the environmental cycling of trace elements. Adv Agron. 20, 235,1968

27. JIA D.A., ZHOU D.M., WANG Y.J., ZHU H.W., CHEN J.L. Adsorption and cosorption of $\mathrm{Cu}$ (II) and tetracycline on two soils with different characteristics. Geoderma, 146 (1-2), 224, 2008.

28. WANG X.F. Resource potential analysis of ornamentals applied in contaminated soil remediation, a dissertation in Graduate School of Chinese Academy of Sciences, Beijing, 2005.

29. TAUQEER H.M., ALI S., RIZWAN M., ALI Q., SAEED R., IFTIKHAR U., AHMAD R., FARID M., ABBASI G.H. Phytoremediation of heavy metals by Alternanthera 
bettzickiana: Growth and physiological response Ecotoxicology and Environmental Safety, 126, 138, 2016.

30. BAI R, CHAO G., SUN H., FAN M., SUN Z. Toxicity of cadmium on the seed germination and growth of Althaea rosea and Orychophragmus violace. Acta Agriculturae Boreali-Sinica, 2, 2009

31. KRZEMIŃSKA-FLOWERS M., BEM H., GÓRECKA $H$. Trace metals concentratio in size-fractioned urban air particulate matter in Łódź, Poland. I. Seasonal and site fluctuations. Pol. J. Environ. Stud., 15 (5), 759, 2006.

32. KRAMER U. Phytoremediation: novel approaches to cleaning up polluted soils. Current Opinion in Biotechnology., 16 (2), 133, 2005.

33. KURTYKA R., MAŁKOWSKI E., KITA A., KARCZW. Effect of calcium and cadmium on growth and accumulation of cadmium, calcium, potassium and sodium in maize seedlings. Pol. J. Environ. Stud., 17, 51, 2008.

34. BUSZEWSKI B., JASTRZĘBSKA A., KOWALKOWSKI T., GÓRNA-BINKUL A. Monitoring of selected heavy metals uptake by plants and soils in the area of Torun, Poland. Polish Journal of Environmental Studies, 9 (6), 511, 2000.

35. VIARD W., PIHAN F., PROMEYRAT S., PIHAN J.C. Integrated assessment of heavy metal $(\mathrm{Pb}, \mathrm{Zn}, \mathrm{Cd})$ highway pollution: Bioaccumulation in soil, Graminaceae and land snails. Chemosphere, 55, 1349, 2004.

36. SEMBRATOWICZ I., RUSINEK E., OGNIK K., TRUCHLINSKI J. Con-centratio of trace elements and heavy metals at selected medicinal plants harvested in two vegetation periods. Herba Pol., 55, 22, 2009.
37. LUGININA E.A., EGOSHINA T.L. The peculiarities of heavy metals accumulation by wild medicinal and fruit plants. Ann Wars Univ Life Sci Agric., 61, 97, 2013.

38. ORDAK M., WESOLOWSKI M., RADECKA I., MUSZYNSKA E., BUJALSKA-ZAZDROZNY M. Seasonal variations of mercury levels in selected medicinal plants originating from Poland. Biological Trace Element Research, 173 (2), 514, 2016.

39. LIU J.N., ZHOU Q.X., WANG S., SUN T. Cadmium tolerance and accumulation of Althaea rosea Cav. and its potential as a hyperaccumulator under chemical enhancement. Environ Monit. Assess., 149, 419, 2009.

40. AMMAR N.M., EL-KASHOURY E.A., EL-KASSEM L.T., ABD ELHAKEEM R.E. Evaluation of the phenolic content and antioxidant potential of Althaea rosea cultivated in Egypt. Journal of Arab Society for Medical Research, 8 (2), 48, 2013.

41. LIU F., DU W., BAI X., TIAN S. Quantification of phytochemical constituents and in-vitro antioxidant activity of Althaea rosea seeds. J. Chem. Pharm. Res., 6 (3), 1466, 2014.

42. ABD EL-SALAM N.M., RADWAN M.M., WANAS A.S., SHENOUDA M.L., SALLAM S.M., PIACENTE S., ELSOHLY M.A., GHAZY N.A. Phytochemical and biological evaluation of Alcea rosea L., growing in Egypt. Planta Med., 82, 2016.

43. YENER S.H., YARCI C. Alcea pallida Waldst. et Kit. (Malvaceae) as a heavy metal biomonitor in Istanbul (Turkey). Fresenius Environmental Bulletin, 19, 1024, 2010. 
